\title{
Unlocking effective transgene expression potential in gene therapy with viral vectors
}

\author{
Nur Shuhaidatul Sarmiza Abdul Halim, Noor Hanis Abu Halim, Lelamekala Vengidasan, Norashikin Zakaria, \\ Ida Shazrina Ismail, Badrul Hisham Yahaya*(-)
}

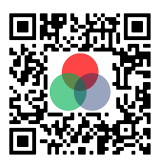

Use your smartphone to scan this QR code and download this article

Lung Stem Cell and Gene Therapy Group, Regenerative Medicine Cluster, Advanced Medical and Dental Institute (IPPT), Universiti Sains Malaysia, Sains@Bertam 13200 Kepala Batas,

Penang Malaysia

Correspondence

Badrul Hisham Yahaya, Lung Stem Cell and Gene Therapy Group, Regenerative Medicine Cluster, Advanced Medical and Dental Institute (IPPT), Universiti Sains Malaysia, Sains@Bertam 13200 Kepala Batas, Penang Malaysia

Email: badrul@usm.my

History

- Received: Aug 09, 2021

- Accepted: Sep 22, 2021

- Published: Oct 06, 2021

DOI : 10.15419/bmrat.v8i10.695

\section{Check for updates}

\section{Copyright}

(c) Biomedpress. This is an openaccess article distributed under the terms of the Creative Commons Attribution 4.0 International license.

\begin{abstract}
Gene therapy is an experimental approach for treating or preventing disease by using genes. Due to its promised therapeutic benefits for various diseases, this technology has drawn much interest in recent years. Despite reports of adverse events caused by gene therapies, success stories have increasingly emerged. The key to the success of gene therapy is finding a suitable DNA vector that will transport the gene into host cells, thus leading to the expression of the desired protein. An effective vector must be very efficient in delivering a gene to the target cells, non-toxic and safe to patients, inexpensive, and simple to use. This review discusses various aspects of the viral vectors currently in use in gene delivery systems and their great potential to unlock effective transgene expression in gene therapy applications based on this platform.

Key words: Gene delivery, gene therapy, therapeutic gene, viral vector, the transfer vector
\end{abstract}

\section{INTRODUCTION}

Gene therapy has been defined by the United States (US) Food and Drug Administration (FDA) as a technique that modifies a person's genes to treat or cure disease (FDA, 2019). On May 22, 1989, Rosenberg and his team attempted the first therapeutic gene transduction using retrovirus-mediated gene transfer, transferring the neo gene into human tumorinfiltrating lymphocytes (TILs). The first-ever approved gene therapy transfer was performed to treat adenosine deaminase severe combined immunodeficiency (ADA-SCID) in 1990. Since then, gene therapy has been regarded as a promising treatment for various inherited or acquired diseases such as cystic fibrosis $(\mathrm{CF})^{1}$, sickle cell anemia ${ }^{2}$, heart disease ${ }^{3}$, cancer $^{4}$, and acquired immunodeficiency syndrome (AIDS) ${ }^{5}$. Gene therapy is used to treat or improve the patient's health condition by delivering exogenous therapeutic genes into the nucleus of target cells. This procedure is performed to treat disorders by correcting the loss-offunction genetic mutation, inhibiting the expression of the disease-causing gene and protein, or expressing the deficient gene product at physiological levels ${ }^{6}$.

Successful gene therapy involves three critical steps: identifying the faulty gene responsible for the disease, locating the corresponding 'correcting gene' or therapeutic gene, and administering gene therapy. A therapeutic gene is a biological product that, when administered into host cells, can regulate genetic sequences and add, delete, replace, or repair genetic sequences. An additional step involves determining a suitable vehicle, known as a vector, to deliver the therapeutic gene into the targeted host cells. Success in gene therapy is largely determined by the effectiveness of the gene delivery method; thus, selecting an appropriate vector is the most essential and difficult aspect of gene therapy. Different viral gene delivery methods and their advantages and drawbacks are described in this study. Clinical trials for human gene and cell-based gene therapy products authorized by the FDA are also included.

\section{GENE DELIVERY SYSTEM}

An efficient gene delivery system is crucial to ensure successful gene transfer. The ideal gene therapy vector should efficiently target the right cells and effectively deliver the therapeutic gene to the targeted site, such as the cytoplasm or nucleus of host cells. The vector should also demonstrate a dose-response relationship and have a low-risk profile in clinical trials. Several clinical trials of viral vectors failed to achieve optimal therapeutic outcomes. The reasons discussed include poor rates of delivery to the target cells ${ }^{7}$, and subsequently lower efficacy at the target site, as well as inconsistent transduction efficiency ${ }^{8,9}$. The human body is naturally equipped with a sophisticated defense system; hence, circumventing the immune response to the vector is one of the major challenges faced by the gene delivery system. A delivery system 
must first overcome extracellular barriers (e.g., the delivery system must protect the DNA from degradation, resist deactivation by other extracellular components, and target specific cells or tissues) and then deal with cellular barriers (e.g., the delivery system must promote cellular uptake, escape endosomes, and facilitate the nuclear entry and release of the DNA). In general, gene delivery systems are classified into two groups: viral and non-viral vectors.

Viral vectors include various viral species with different nucleic acid compositions and characteristic features related to the host cell specificity, expression pattern and duration, and cytotoxicity (Table 1). Viral vectors are mostly genetically modified and replication-defective, offering the advantage of high delivery efficiency to numerous cell types ${ }^{5}$. In particular, viral vectors are responsible for mimicking high-level heterologous gene expression despite constitutive or combined promoters. The nucleic acid composition of each virus determines the features of gene expression. In this regard, viruses carrying single-stranded RNA genomes show a prompt onset of short-term transgene expression. DNA-based vectors, including adenovirus (Ad), are also transient. In contrast, adeno-associated virus (AAV) leads to a high level of long-term gene expression by inefficiently integrating into the host DNA and mostly remaining within the episomal genome ${ }^{10-16}$. Retroviruses (RVs), with a double-stranded RNA genome, can also establish long-lasting expression via chromosomal integration. Furthermore, the herpes simplex virus (HSV) genome typically resides in host cells without causing any visible harm and produces a latent infection. The application of viral vectors in human clinical trials needs critical consideration of safety aspects related to their use. The cell-type susceptibility of viral vectors depends mainly on their tropism, whereas non-viral vector systems have almost no cell-type selectivity. Thus, it is not surprising that this area has been the target of intensive research resulting in the development of many vehicles. This article discusses the many types of viral vectors, how they are administered, the clinical trials involved, and the problems and roadblocks they face in gene therapy.

\section{Viral Vectors}

Since the onset of the gene therapy era, viral vectors have been used as a primary vehicle for gene delivery to human cells. In 2019, over 3000 clinical trials related to gene therapy applications were conducted, proving that this field is gaining significant interest ${ }^{\mathbf{1 4}}$.
The clinical trials focused on cancer therapy, monogenic diseases, infectious diseases, and cardiovascular diseases. Interestingly, although more efficient nonviral vector-based methods have been developed recently, viral vectors were used in nearly $70 \%$ of the trials.

The recombinant viral vectors often used in gene therapy applications include Ad, RV, lentivirus (LV), $\mathrm{HSV}$, and AAV, which range in their genomic size from $\sim 5$ to $150 \mathrm{~kb}$. The suitability of each type of viral vector for different applications is decided based on various features. There are two major classes of recombinant viral vectors generally used to deliver genes, grouped according to whether their genomes exist as extrachromosomal episomes (AAVs, HSVs, and Ads) or integrate into the recipient's chromosome (RVs and LVs). This feature is crucial for determining the suitability of each vector for certain applications. Although many targeted diseases have been responsive to gene therapy, no single vector is suitable for use in all applications. The essential features required of all vectors include assured safety, reproducibility, stability of propagation, the ability to be purified to high titers, and the ability to mediate specific targeted gene delivery, where only the therapeutic gene specific to the tissue or organ of interest is transferred without widespread vector dissemination. The features of these five commonly used viral vectors are discussed in detail in the following section. Table 1 contains an overview of the viral vectors and their comparison.

\section{Adenoviral vectors}

Ads are non-enveloped viruses with a doublestranded DNA genome and icosahedral nucleocapsid. Around 57 previously discovered human Ad serotypes are divided into 7 subgroups $(A-G){ }^{15}$. The most extensively characterized Ads are the 36kb serotypes 2 ( $\operatorname{Ad} 2$ ) and 5 (Ad5), which belong to subgroup C. These Ads, especially those of serotype 5 , are widely used in a broad range of gene therapies because they can transduce various types of dividing and non-dividing cells both in vitro and in vivo ${ }^{\mathbf{1 6}}$. Most recombinant adenoviral systems designed for gene transfer applications are replicationdefective or, in other words, not capable of replicating themselves ${ }^{15,17,18}$. They are constructed into a vector expressing the therapeutic gene, while a helper construct encodes for the viral proteins and makes the virus incapable of replicating ${ }^{19}$. Recombinant Ad vectors are the most efficacious medium by which to deliver genes in vivo. In 2013, 476 human gene therapy studies were conducted using recombinant $\mathrm{Ad}$ 


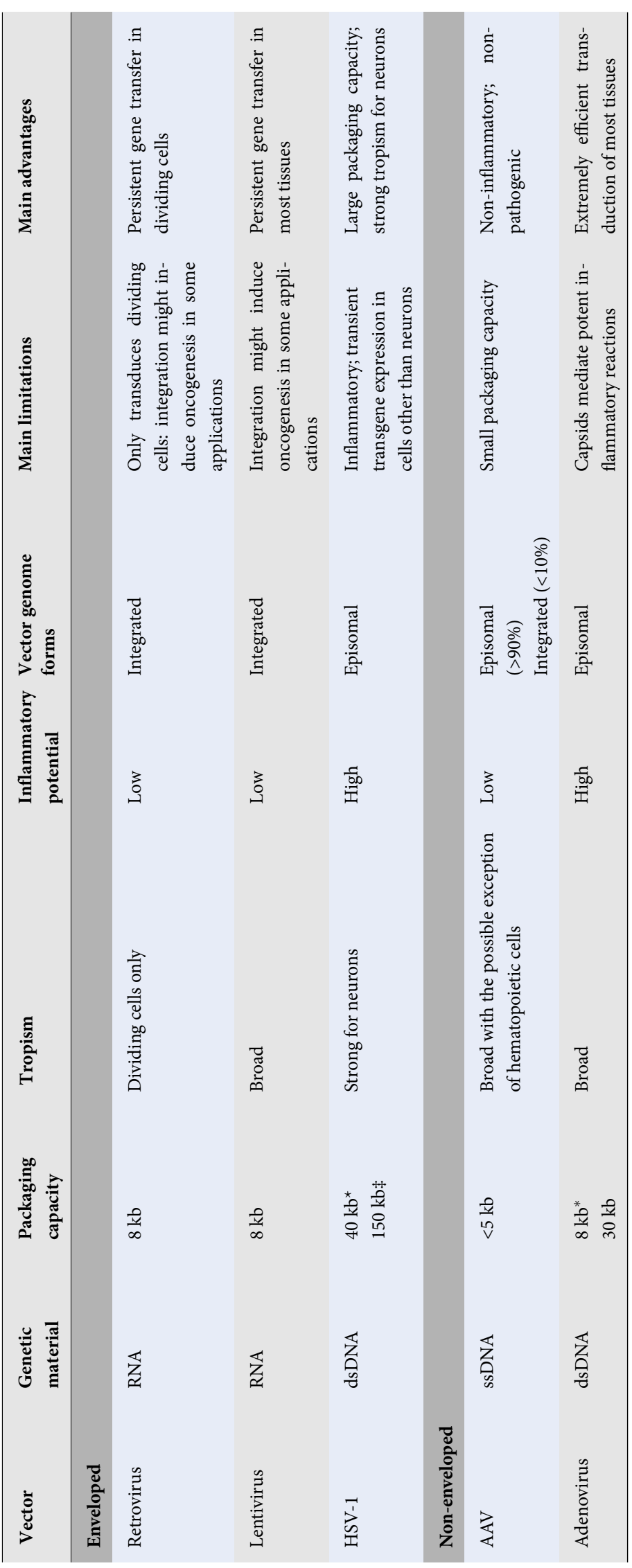


vectors, representing $23.5 \%$ of all gene therapy trials; with this, Ad vectors were recognized as the viral vector most applied in clinical trials globally ${ }^{20}$. This is due to their broad cellular tropism for in vitro and in vivo applications. Despite having significant advantages for various gene therapy applications, Ads lack native integration machinery that would enable the attainment of permanent gene expression in vivo. Ad vectors do not integrate into the host genome and remain episomal. Studies have demonstrated that random integration of replication-defective Ad vectors into the host genome occurred at frequencies of $0.001 \%-1 \%$ of infected cells, reducing the risk of insertional mutagenesis. Current advances have led to the emergence of a range of hybrid vectors combining the vastly efficient DNA delivery of Ads with the integration machinery of RVs, AAVs, and transposons to improve the integration frequencies of Ad vectors. These hybrid vectors have shown promise, at least in in vitro systems ${ }^{21}$.

Ad vectors are highly immunogenic and can induce strong innate and adaptive immune responses. Recombinant Ad vectors have been constructed by deleting numerous parts of their coding regions. The first-generation Ad vectors were made by substituting the early gene (E1) with a transgene. Although the deletion of $\mathrm{E} 1$ resulted in a replication-defective vector, the E2, E3, and E4 promoters remained active and led to the expression of viral genes at low levels ${ }^{15}$. This leaky viral protein expression induced strong cytotoxic immune reactions that rapidly eliminated transgene expression in transduced cells ${ }^{19}$. Additional attempts were made to delete several early genes (E2a, E2b, or E4) besides E1 to reduce the immune response to the viral antigens produced due to leaky expression. Although these second-and thirdgeneration Ad vectors reduced toxicity, the gene sequences encoding the viral particles remained active, leading to the expression of viral proteins that induced secondary innate and adaptive immune responses against the vectors ${ }^{22,23}$. Because of these factors, the sufficient expression period for Ad vectors in vivo in humans peaks at 1 week and is restricted to about 2 weeks, making these vectors ideal for use whenever a shorter duration of vector expression is required, such as for generating new biological structures $^{20}$. Despite the safety of Ad vectors, considering the immune response against them, helper-dependent Ad (HDAd) vectors with large-scale cloning capacity were introduced. All viral genes except the inverted terminal repeats and packaging signal are deleted in these HDAd vectors ${ }^{\mathbf{2 4}}$. HDAd vectors were found to reduce chronic toxicity in comparison to the first- and second-generation viruses in which only a part of the viral genome was deleted ${ }^{25}$. Although the safety profiles of HDAd vectors were improved, the dose of the vector was shown to trigger an acute immune response mediated by capsid proteins of the vector in a dose-dependent manner ${ }^{26}$.

To sum up, Ad has a high transduction capacity and is the most effective gene delivery method in cell and tissue types of varying complexity. The strong inflammatory response to the virus's capsid proteins is the greatest flaw of the Ad system. It is anticipated that additional development will soon provide patients with efficient and safe Ad gene transfer.

\section{Retroviral vectors}

RVs, which are enveloped viruses with RNA genomes, can reverse transcribe their genetic material from RNA to cDNA. Most recombinant RV systems are replication-defective, and a transgene expression vector along with a helper virus that expresses viral proteins are used in gene therapy applications. However, the ability of the virus to replicate is limited. Packaging features are provided by the helper virus that carries co-transfected plasmids in a packaging cell (e.g., the HEK293 cell line). The packaging cell lines encode sequences involved in viral packaging functions (gag, pro, pol, and env). These genes cannot be packaged into RV particles because they are supplied during transformation using molecular constructs. The transgene is delivered into a genetic vector that mimics the viral genome structure but contains fewer cisacting sequences, permitting its effective incorporation into viral particles, reverse transcription, and expression in target cells.

The use of RV vectors is a classic approach in longterm gene therapy applications, and RVs have been used to deliver transgenes for the past three decades ${ }^{9}$. As the gold standard, RV vectors could accommodate up to $8 \mathrm{~kb}$ of foreign genes and were proven effective in ex vivo therapies involving bone marrow stem cell transplants ${ }^{27}$. The most commonly used $\mathrm{RV}$ vector is derived from the murine leukemia virus (MLV). In 1990, the first human gene therapy using MLV-based gamma-retroviral $(\gamma$-RV) vectors carrying therapeutic genes was performed in two young girls suffering from severe combined immunodeficiency (SCID). The clinical trial involved the implantation of autologous bone marrow cells transduced ex vivo with gamma $\mathrm{RV}$ vectors ${ }^{28,29}$. Although the clinical trial restored T-cell immunity in the SCID patients, vector-induced insertional oncogenesis due to random incorporation of the vector into the host 
genome was identified as a significant issue ${ }^{30-32}$. Another limitation of RVs is their inability to infect nondividing cells, which enhanced the interest in applying LV vectors for gene therapy. LVs are capable of infecting both dividing and non-dividing cells even though they belong to the RV family. Therefore, LVs exhibit low cytotoxicity ${ }^{33}$.

In sum, because of their persistent and long-term gene transfer in proliferating cells, RVs are a promising option for gene transfer. However, RVs only transduce diving cells and integration may lead to oncogenesis in certain cases.

\section{Lentiviral vectors}

LVs are a type of RVs. Scientists showed interest in LVs for the first time in the early 1980s when the AIDS pandemic introduced the world to the most well-known and feared LV: human immunodeficiency virus type 1 (HIV-1). Since replicationdefective LVs derived from HIV-1 can incorporate into the genome of non-dividing cells such as neurons and hematopoietic stem cells (HSCs) with a sustained, long-term expression of therapeutic genes, they were adopted as vehicles for gene delivery ${ }^{33}$. This is a unique feature of LVs as other RVs require proliferating cells to integrate into the cellular genome ${ }^{34}$. These properties underscore the potential benefits of using LVs over other RV vectors in human gene therapy applications. Naldini et al. (1996) were the first to show that LVs derived from HIV-1 could offer efficient preclinical gene delivery, stable incorporation into the cellular genome, and constitutive expression of the therapeutic genes in non-dividing cells such as neurons ${ }^{35}$. However, potent host immune responses against the LV capsid and/or their transgene products hinder the success of gene therapy using LV vectors. The transgene expression period and potency of immune reactions to LV-encoded transgene products have differed among studies on in vivo delivery. The efficacy of LV vector-mediated gene delivery in immunocompetent mice leads to effective transduction and transgene expression in various cell types, including the retina, muscle, and hematopoietic cells, but the transduction of hepatocytes is relatively inefficient.

LVs function like RVs in that the genomic RNA of LVs is reverse-transcribed into cDNA as the virus invades the cells. The cDNA produced is then integrated into the cellular genome with the aid of a viral integrase enzyme at a random site. The integrated viral genome, now recognized as a provirus, remains in the host genome and is transferred to cell progeny as the cells undergo division. However, the integration site cannot be predicted, which may lead to some issues. The function of cellular genes may be interrupted by the provirus, inducing oncogene activation and enhancing carcinogenesis, raising safety concerns around the use of LVs in gene therapy.

Nevertheless, a few studies showed that the selection of LV insertion sites differs from that of RVs such as $\gamma$-RV vectors. This could be due to the differences in the structure of the integrase enzyme of these two types of viruses and the viral long terminal repeats (LTRs) in the $\gamma$-RV vectors. LVs incorporate randomly throughout the genome, although they only target active transcription units. On the other hand, the integrase and LTRs of $\gamma$-RV vectors were found to promote selected interaction with active host cell promoters and enhancers ${ }^{36}$. A previous study conducted by Aiuti et al. suggested that lentiviral gene therapy is safer than retroviral gene therapy since LVs have a lower risk of causing insertional mutagenesis. This lentiviral gene therapy did not promote the selection of integration sites near oncogenes and there was no aberrant clonal expansion detected ${ }^{37,38}$.

The use of lentiviral vectors in gene therapy has emerged owing to the persistence of gene transfer in most tissues after the insertion of the vector. Its biggest flaw is integration possibly leading to oncogenesis in certain situations.

\section{Herpes simplex virus vector}

HSV s are large, enveloped viruses belonging to the $\mathrm{Al}$ phaherpesvirinae subfamily of the family Herpesviridae. Amongst the herpesviruses, HSV serotype 1 (HSV-1) has several natural properties that make it attractive for use as a viral vector, particularly for treatments related to diseases of the nervous system ${ }^{12,39}$. In contrast to other viral systems, HSV-1derived vectors can package and efficiently transfer up to $150 \mathrm{~kb}$ of transgenes to the nucleus of mammalian cells. HSV-1-based vectors can accommodate multiple transgene cassettes or single large genes, which is very practical for applications that require $97 \mathrm{ex}$ pressions of one or a few gene products for an effective therapeutic outcome (e.g., tumor-killing). HSV1-based vectors can infect many cell types, including both dividing and non-dividing cells; however, they cannot incorporate into cellular DNA ${ }^{\mathbf{4 0 , 4 1}}$. These viruses lack lytic viral protein production and thus are episomal. Interestingly, latent, lifelong infections in the nervous system with the long-term expression of the transgene in brain neurons and without any leaky expression of the viral genes make HSV vectors a promising vehicle for gene delivery to the central nervous system $(\mathrm{CNS})^{42}$. Several clinical studies using 
HSV vectors were performed to test therapies against recurrent breast cancer, head and neck cancer, unresectable pancreatic cancer, refractory superficial cancer, melanoma, and other conditions, mainly neurological and pain disorders ${ }^{43}$.

Amplicons are vectors harboring only a minimal number of virally derived sequences and are non-integrative, replication-defective, and helperdependent HSV-1-derived vectors. They have the same properties as typical HSV-1 particles, including structure, tropism, and immunogenicity. However, they carry a concatemeric DNA plasmid containing the HSV-1 origin of replication (ori), HSV-1 packaging signal (pac), and transgene rather than a functional HSV genome ${ }^{44}$. These sequences enable the packaging of infectious HSV-1 particles. HSV-1 amplicon vector systems offer some advantages in gene therapy. They do not carry any viral genes, providing more space to accommodate larger foreign DNA molecules (up to almost $150 \mathrm{~kb}$ ). These advantages make the HSV vector a powerful, interesting, and useful gene delivery tool.

Amplicons are completely safe for inoculation in animals, non-toxic to the infected cells, and only induce low levels of the adaptive immune response because they do not encode any viral proteins ${ }^{45}$. Like other HSV vectors, amplicons remain episomal, therefore posing no risk of insertional mutagenesis. Moreover, HSV-1 naturally spreads in the nervous system via neuronal transport, and it infects several species, which is useful for the in vivo assessment of vectors in various animal models. Transduction in the brain is generally more effective with HSV vectors than with other vectors (lower titers are required) since neurons are the natural target for HSV-1 infection.

To summarize, the benefits of HSV-1 vectors include their ability to infect both quiescent and proliferating cells effectively as well as their ability to encode for transgenes of significant size. On the other hand, when primary fibroblasts are used, there is a rapid reduction in the expression of the transgene.

\section{Adeno-associated virus vector}

AAV, a small, non-enveloped virus that infects human cells, is naturally replication-defective and does not cause disease in humans. So far, AAV appears to be the most promising means of gene delivery in vivo since the wild-type virus has never been reported to cause any disease in humans ${ }^{46,47}$. The general principles of recombinant AAV (rAAV) vector construction involve the modification of molecular clones by replacing the AAV coding gene sequence with exogenous DNA to generate a plasmid vector. Recombinant vectors derived from these viruses are composed of two inverted terminal repeats flanking an expression cassette encoding a therapeutic transgene, deleting all viral open reading frames. To propagate rAAVs, co-infection with a helper virus, mainly Ad, is required ${ }^{47}$. This system facilitates rAAV production at relatively high titers. However, this preparation is contaminated with the helper virus and therefore needs further purification. For gene therapy applications in humans, this requirement for co-infection offers a natural safety feature that helps prevent the improper spread of rAAVs following clinical administration.

AAVs have a good safety profile for use as a vector in gene therapy. Because of the absence of viral genes, AAVs do not cause a deleterious host immune response ${ }^{47}$. A clinical trial in hemophilia B patients using an AAV-2 vector resulted in long-term expression in skeletal muscles and deficient inflammatory responses ${ }^{48,49}$. However, the effectiveness of AAVs relies on the serotype, administration route, effective multiplicity of infection of the vector employed, transgene and expression cassette, and dosing schedule of injection ${ }^{50}$. Although AAV vectors have low immunogenicity, a primary host immune response (e.g., a neutralizing antibody response) may be elicited against the vector capsid protein or transgene product, which might impact their use. For example, the decline in expression of the factor IX transgene 6 weeks after hepatic gene transfer and destruction of hepatocytes have been observed in patients in the highest dose cohort. Other significant positive features of AAV vectors include their efficacy in transducing proliferating cells as well as non-proliferating tissues, such as neurons, photoreceptor cells, hepatocytes, and muscle cells in vivo and their promotion of the long-term expression of transgenes in vivo. This is due to their integration into the host chromosome. Although AAV vector genomes can persist within cells as episomes, vector integration has been seen in numerous experimental settings ${ }^{\mathbf{5 1}}$. About 20 AAV vectors were used in clinical settings for various therapeutic and prophylactic applications (e.g., hemophilia B and CF) ${ }^{\mathbf{5 2}}$. As of 2020, AAV vectors have been used in more than 12 clinical studies on hemophilia alone ${ }^{\mathbf{5 3}}$.

Although AAV has a good safety profile compared to other viruses and may mediate long-term gene expression in non-proliferating or slowly proliferating cells, it is limited by several factors. For example, the immune response was shown to be triggered by the 
repeated administration of AAV vectors ${ }^{54}$. To overcome this problem, a different AAV serotype is applied for each re-administration. Another related issue is the very small packaging size of AAV $(\sim 4.7 \mathrm{~kb})$, which limits the size of transgenes that can be packaged into the vector ${ }^{55}$. AAV vectors are unable to efficiently infect certain types of cells, such as HSCs, which are considered potential targets for numerous gene therapy applications. Furthermore, the safety of AAVs as a vector in clinical applications is limited because of concerns about AAV integration-mediated tumorigenicity. A previous study reported that the development of hepatocellular carcinoma was associated with AAV gene delivery in mice ${ }^{\mathbf{5 6}}$.

AAVs offer similar benefits to Adv vectors, such as high transduction efficiency and long-lasting transgenic expression. They have a high biosafety rating and low immunogenicity, making them a good choice for gene therapy. However, AAVs also have several drawbacks, including a reduction in transgene expression over time due to episomal integration and a modest packaging capacity.

\section{ADMINISTRATION ROUTES AND THEIR IMPORTANCE}

Gene therapy can be performed either in vivo or ex vivo, and the modality is decided based on other factors such as the nature of the cell, required expression levels, and safety. The in vivo technique involves directly injecting the target gene into patients, while the ex vivo method involves isolating and transfecting cells in vitro before reinjecting them into patients. Selecting administration routes for targeted gene delivery is crucial to determine the in vivo fate of the administered viral vector. Administration routes may be divided into two categories: systemic routes and local (topical) routes. The method of administration used to deliver the transgene is one of the variables that influence its expression. Oral, intravenous (IV), and topical administration routes are all options for viral vectors.

\section{Oral administration}

Oral gene therapy remains a promising and attractive strategy despite its challenges and obstacles. Oral administration holds great promise as it allows the daily intake of genetic medicine, easing the administration route and allowing transient gene expression. The idea of oral gene therapy is exciting because the body is not subjected to invasive surgery or deep wounds or exposed to local drug effects upon administration. Gene therapy clinical trials using oral administration that are actively recruiting participants include those testing treatments for typical Canavan disease in children ${ }^{57}$ and high-risk prostate cancer ${ }^{58}$ using AAV and Ad, respectively. The main obstacles to effective oral administration of gene therapy include withstanding harsh and everchanging conditions, such as the acidic $\mathrm{pH}$ and degradative enzymes in the gastrointestinal tract, without compromising the transgene while simultaneously maintaining efficiency.

\section{IV administration}

IV administration, also known as systemic delivery, is one of the most preferred viral gene delivery methods. IV administration is well tolerated at higher viral doses and provides a high level of gene expression. It has been reported as an effective and safe route for cancer gene therapy using HSV ${ }^{59}$. One of the system's limitations is its broad distribution of vectors throughout the body that can easily lead to side effects. For instance, liver tropism is often observed after Ad administration through the IV route.

\section{Topical administration}

One of the major challenges in gene delivery is to deliver the transgene specifically to the target tissue; in this regard, local gene delivery holds great potential compared to systemic gene delivery. In the last 5 years, $40 \%$ of ongoing Phase III clinical trials on cancer gene therapy have utilized local gene delivery systems. A study on bevacizumab delivery using an AAV gene system showed sustained gene expression with less off-target effects and toxicity in lung cancer ${ }^{\mathbf{6 0}}$. Another study showed that regional IV application using suitable AAV vectors has the most promise as a gene therapy approach for ischemic heath disease ${ }^{\mathbf{6 1}}$. Local delivery, like pleural delivery, was also shown to have little risk of gene- or virus-induced inflammation $^{62}$.

\section{GENE THERAPY CLINICAL TRIALS}

According to a database provided by the Journal of Gene Medicine in their Gene Therapy Clinical Trials worldwide site, 3143 gene therapy studies have been performed globally thus far (http://www.wiley.co.uk/ genmed/clinical, updated on Sept 2019). Initial clinical trials focused on monogenic diseases. However, cancer has become a major topic of interest in recent years $(\sim 67 \%)$, followed by monogenic, cardiovascular, infectious, and neurological diseases (Figure 1). Based on the clinical trials performed, virus vectors were found to be more efficient than non-viral vectors. As many as $67 \%$ of the clinical trials used viral vectors, including Ads, RVs, AAVs, LVs, vaccinia virus, 


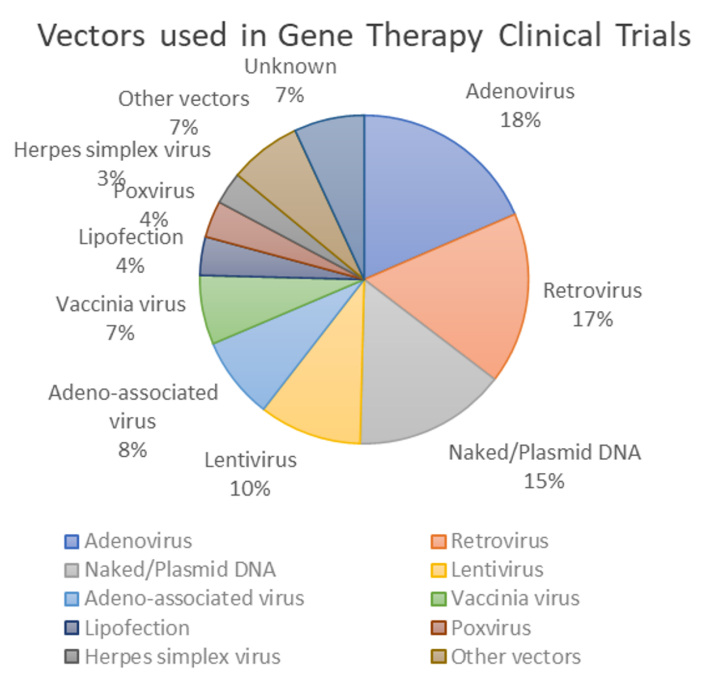

The Journal of Gene Medicine, 2019 John Wiley and Sons Ltd

\section{Diseases Addressed by Gene Therapy Trials}

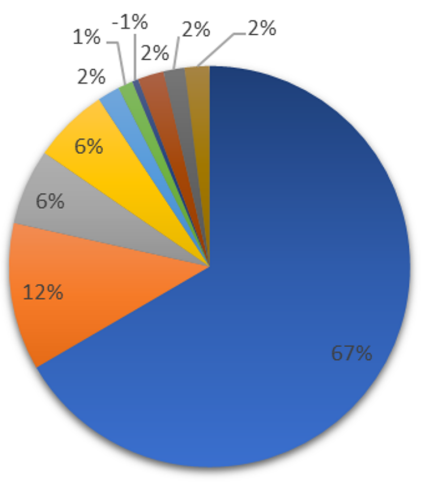

$$
\begin{aligned}
& \text { - Cancer diseases } \\
& \text { nonogenic diseases } \\
& \text { - Infectious diseases } \\
& \text { - Cardiovascular diseases } \\
& \text { - Neurological diseases } \\
& \text { n Ocular diseases } \\
& \text { - Inflammatory disease } \\
& \text { - Other diseases } \\
& \text { - Gene marking } \\
& \text { - Healthy volunteers }
\end{aligned}
$$

The Journal of Gene Medicine, 2019 John Wiley and Sons Ltd

Figure 1: Percentage of gene therapy trials devoted to different patient groups. Initial clinical trials focused on monogenetic diseases. However, cancer has become a major interest in recent years. https://doi.org/10.6084/ m9.figshare.16752061.v1

poxvirus, and HSVs (Figure 1). An updated list of all approved gene therapy products, including viral and non-viral vectors, is given in Table 2. 
Table 2: List of Approved Gene Therapy Products (adapted from ${ }^{63,64}$ )

\begin{tabular}{|c|c|c|c|c|c|}
\hline Trade name & Approvalauthority(date) & Indication & Manufacturer & Clinical trial I.D. & Vector \\
\hline $\begin{array}{l}\text { Fomivirsen } \\
\text { (vitravene) }\end{array}$ & $\begin{array}{l}\text { USA FDA (1998) } \\
\text { EMA (1999) }\end{array}$ & tCMV retinitis & $\begin{array}{l}\text { ISIS Pharmaceuticals with } \\
\text { Novartis Ophthalmics }\end{array}$ & $\begin{array}{l}\text { NCT00002187 } \\
\text { NCT00002156 } \\
\text { NCT00002356 } \\
\text { NCT00002355 }\end{array}$ & $\begin{array}{c}\text { ASO - inhibition of } \\
\text { immediate-early IE-2 } \\
\text { protein }\end{array}$ \\
\hline Gendicine & $\begin{array}{l}\text { State Food and Drug } \\
\text { Administration of China } \\
(2003)\end{array}$ & $\begin{array}{l}\text { Head and neck squamous cell } \\
\text { carcinoma }\end{array}$ & $\begin{array}{l}\text { Shenzhen SiBiono GeneTech } \\
\text { (Shenzhen, China) }\end{array}$ & $\begin{array}{l}\text { ChiCTR-TRC-08000094 } \\
\text { ChiCTR-TRC-08000092 } \\
\text { ChiCTR-TRC-08000091 }\end{array}$ & Adenovirus \\
\hline H101 (Oncorine) & $\begin{array}{l}\text { China FDA } \\
(2005)\end{array}$ & $\begin{array}{l}\text { Patients with last stage head } \\
\text { and neck cancer, lung cancer, } \\
\text { liver cancer, malignant pleural } \\
\text { and peritoneal effusion and } \\
\text { pancreatic cancer }\end{array}$ & Shanghai Sunway Biotech & NCT02579564 & Adenovirus \\
\hline Rexin-G & $\begin{array}{l}\text { Philippine FDA } \\
(2007) \\
\text { USA FDA } \\
(2010)\end{array}$ & $\begin{array}{l}\text { A solid metastatic tumour } \\
\text { (pancreatic, breast cancer, } \\
\text { osteosarcoma, sarcoma }\end{array}$ & Epeius biotechnologies & $\begin{array}{l}\text { NCT00505271 } \\
\text { NCT00572130 } \\
\text { NCT00505713 } \\
\text { NCT00504998 } \\
\text { NCT00121745 }\end{array}$ & Retrovirus \\
\hline $\begin{array}{l}\text { Neovasculgen } \\
\text { (PI-VEGF165) }\end{array}$ & $\begin{array}{l}\text { Russian ministry of } \\
\text { healthcare (2012) }\end{array}$ & $\begin{array}{l}\text { Atherosclerotic peripheral arte- } \\
\text { rial disease (PAD) }\end{array}$ & Human stem cells institute & $\begin{array}{l}\text { NCT03068585 } \\
\text { NCT02538705 } \\
\text { NCT02369809 }\end{array}$ & CMV \\
\hline $\begin{array}{l}\text { Glybera (alipogene } \\
\text { tiparvovec) }\end{array}$ & EMA (2012) & Lipoprotein lipase deficiency & $\begin{array}{l}\text { uniQure (Amsterdam, } \\
\text { Netherlands) }\end{array}$ & $\begin{array}{l}\text { NCT02904772 } \\
\text { NCT03293810 }\end{array}$ & AAV1 \\
\hline Strimvelis ${ }^{\mathrm{TM}}$ & EMA (2016) & $\begin{array}{l}\text { Adenosine deaminase } \\
\text { deficiency (ADA-SCID) }\end{array}$ & $\begin{array}{l}\text { GlaxoSmith-Kline (Middlesex, } \\
\text { United Kingdom) }\end{array}$ & NCT00598481 & Retrovirus \\
\hline Zalmoxis & $\begin{array}{l}\text { EMA } \\
(2016)\end{array}$ & $\begin{array}{l}\text { Hematopoietic stem cell trans- } \\
\text { plantation graft vs. host disease }\end{array}$ & MolMed SPAA & $\begin{array}{l}\text { TK007 } \\
\text { TK008 } \\
\end{array}$ & Retrovirus \\
\hline
\end{tabular}




\begin{tabular}{|c|c|c|c|c|c|}
\hline \multirow{6}{*}{$\begin{array}{l}\text { Table } 2 \text { continued } \\
\text { Trade name } \\
\text { Imlygic }\end{array}$} & \multirow[b]{2}{*}{ Approvalauthority(date) } & \multirow[b]{2}{*}{ Indication } & \multirow[b]{2}{*}{ Manufacturer } & \multirow[b]{2}{*}{ Clinicaltrial I.D. } & \multirow[b]{2}{*}{ Vector } \\
\hline & & & & & \\
\hline & USA FDA & Multiple solid tumors & Amgen & NCT02014441 & HSV-1 oncolytic virus \\
\hline & $(2016)$ & (melanoma, Pancreatic cancer) & & NCT01740297 & \\
\hline & & & & NCT02366195 & \\
\hline & & & & NCT00402025 & \\
\hline Kymriah $^{\mathrm{TM}}$ & USA FDA (2017) & Acute lymphoblastic leukaemia & $\begin{array}{c}\text { Novartis Pharmaceuticals (Basel, } \\
\text { Switzerland) }\end{array}$ & $\begin{array}{l}\text { NCT02435849 } \\
\text { NCT02445248 }\end{array}$ & CART- Lentivirus \\
\hline $\begin{array}{l}\text { Yescarta }^{\mathrm{TM}} \quad \text { (axicab- } \\
\text { tagene ciloleucel) }\end{array}$ & USA FDA (2017) & B-cell lymphoma & $\begin{array}{c}\text { Kite Pharma, Incorporated (Santa } \\
\text { Monica, California, USA) }\end{array}$ & NCT02348216 & CART - Retrovirus \\
\hline $\begin{array}{l}\text { Luxturna }^{\mathrm{TM}} \text { (voreti- } \\
\text { gene neparvovec- } \\
\text { rzyl) }\end{array}$ & $\begin{array}{l}\text { USA FDA (2017) } \\
\text { EMA (2018) }\end{array}$ & $\begin{array}{l}\text { Retinal dystrophy, retinal } \\
\text { pigment epithelial cells }\end{array}$ & Novartis Inc & $\begin{array}{l}\text { NCT00999609 } \\
\text { NCT03602820 }\end{array}$ & AAV2 \\
\hline $\begin{array}{l}\text { INVOSS } \\
\text { (TissueGene-C or } \\
\text { Tonogenchoncel-L }\end{array}$ & $\begin{array}{l}\text { South Korea's MFDS } \\
(2017)\end{array}$ & $\begin{array}{l}\text { Kellgren-Lawrence Grade } 3 \\
\text { knee osteoarthritis }\end{array}$ & $\begin{array}{c}\text { TissueGene (now called Kolon } \\
\text { TissueGene) }\end{array}$ & $\begin{array}{l}\text { NCT01221441 } \\
\text { NCT03412864 }\end{array}$ & Retrovirus \\
\hline Zolgensma & $\begin{array}{l}\text { USA FDA } \\
(2019)\end{array}$ & $\begin{array}{l}\text { Pediatric individuals less than } \\
2 \text { years of age diagnosed SMA } \\
\text { having biallelic mutations in } \\
\text { the SMN1 gene }\end{array}$ & AveXis/Novartis & $\begin{array}{l}\text { NCT03421977 } \\
\text { NCT03505099 } \\
\text { NCT03421977 } \\
\text { NCT02122952 } \\
\text { NCT0330627 } \\
\text { NCT03461289 }\end{array}$ & Recombinant AAV9 \\
\hline
\end{tabular}


The earliest study on gene therapy was conducted in 1989 at the National Institute of Health by Rosenberg et al. (1990), in which a retroviral vector was used to transfer a neomycin resistance marker gene into TILs from five metastatic melanoma patients ${ }^{65}$. Adoptive transfer of TILs, previously reported to have unique lytic specificity for autologous tumors, along with interleukin-2, resulted in tumor regression. This successful ex vivo study proved that transferring genes using RV is practical, leading to many other studies ${ }^{\mathbf{6 6}}$. In 2000, the first successful gene-based clinical trial was performed. An RV vector was used to treat 20 infants suffering from SCID-X1 ${ }^{63}$. A trial conducted in France on long-term exposure to RV revealed that eight out of nine treated patients were alive after a median period of 9 years. However, four developed leukemia after 30 months of treatment ${ }^{31}$.

In the context of HSV-based clinical trials, an oncolytic HSV-HF10 vector has been used in various clinical trials on recurrent breast cancer, head and neck cancer, unresectable pancreatic cancer, refractory superficial cancer, and melanoma ${ }^{43}$. These clinical trials showed high safety and a low frequency of adverse effects in treated patients. In Phase I clinical trials, the oncolytic HSV G207 vector lacking genes essential for replication in normal cells was evaluated in patients with recurrent glioblastoma multiforme ${ }^{67}$. No patients were found to develop HSV encephalitis, but significant antitumor activity was observed following two doses of HSV G207. In another Phase I clinical trial, six of nine patients had stable disease or partial response. The median survival time was 7.5 months after a single dose of oncolytic HSV was injected into patients with recurrent/progressive highgrade glioma, indicating the potential for clinical response ${ }^{68}$.

Ads, AAVs, and Sendai virus (SeV) have been acknowledged as effective gene therapy vectors to treat CF. The first CF gene therapy study involving a viral vector was reported in the early 1990s, where Ad serotype 2 was used to transfer the CF transmembrane conductance regulator (CFTR) gene encoding human cDNA to the nasal epithelium of three CF patients ${ }^{69}$. This study successfully provided proof-ofconcept of correcting defects in the chloride transport system using the Ad vector and led to further studies using adenoviral vectors. Human parainfluenza virus (HPIV) and SeV were also shown to efficiently transfer genes into airway epithelial cells ${ }^{70}$. However, only $\mathrm{SeV}$ was demonstrated to partially fix chloride transport defects in CF knockout mice ${ }^{71}$. Since these viral vectors have a natural tropism for the airway epithelium, they only showed transient expression and were inefficient upon repeated administration. Therefore, LVs that can transduce both proliferating and non-proliferating cells were established as the vector for gene transfer in CF treatment ${ }^{72}$. In 2015, the United Kingdom CF Gene Therapy Consortium (UK CFGTC) completed the Phase IIb multiple-dose clinical trial of CFTR-expressing plasmid delivery mediated by liposomes. The CFTR-expressing plasmid was administered once a month for 1 year, and this trial was the first to demonstrate that gene therapy may serve the moderate stabilization of lung function in CF patients ${ }^{73}$.

Apart from CF, the substantial advancement of the LV-based gene therapy approach has led to promising results for a dozen clinical trials for the treatment of genetic diseases. For instance, autologous $\mathrm{CD} 4^{+}$cells transduced with lentiviral vectors encoding the human $\beta \mathrm{A}$-T87Q-globin gene administered to $18 \beta$-thalassemia patients carrying mutations in the HBB globin gene in Phase I/II clinical trials proved to be successful in replacing long-term allogeneic hematopoietic cell transplantations ${ }^{74}$. There was no significant toxicity related to the vector 3 years post-infusion as found in patient follow-ups. This result directed the development of LentiGlobinBB305, which has now advanced to a multinational Phase III clinical trial for the treatment of $\beta$-thalassemia (NCT03207009 and NCT02906202) and sickle cell disease (NCT04293185) ${ }^{75}$.

At least 12 clinical trials using AAV vectors to treat hemophilia, a severe blood-clotting disease, are currently ongoing. The majority of these clinical trials are in the Phase II/III stages and the tested interventions hence exhibit promise for commercialization. For example, fidanacogene elaparvovec, developed to treat hemophilia B; SPK-8011, gene therapy for hemophilia A; Valrox (valoctocogene roxaparvovec or BMN 270), gene therapy for hemophilia A; and AMT061 , gene therapy for hemophilia $\mathrm{B}$, are currently being tested in phase III clinical trials (NCT03392974 and NCT03569891). FLT180a is also being tested in a Phase II/III study on hemophilia B patients in the UK (NCT03641703) ${ }^{75}$. Apart from hemophilia, a recent Phase I clinical trial to treat age-related macular degeneration (AMD) and diabetic macular degeneration using AAV vectors has shown positive outcomes in terms of disease reversal (NCT03748784). This clinical trial aimed to evaluate the safety and tolerability of a single intravitreal injection of an AAV vector carrying aflibercept (an anti-VEGF fusion protein that blocks blood vessel growth and leakage related to AMD and diabetic retinopathy in patients 
with AMD), correction of visual acuity, and elimination of anti-VEGF rescue injections. The trial resulted in mean best-corrected visual acuity improvements of +6.8 letters and central subfield macular thickness reduction of $-137.8 \mu \mathrm{M}$, indicating disease reversal in patients receiving treatments ${ }^{76}$. This choice of gene therapy is obvious due to the application of the evolved capsid that is strongly tropic to photoreceptors known as AAV2.7m8 $8^{77}$.

Despite many technological challenges and barriers, numerous gene therapy-based drugs have entered the global pharmaceutical market (Table 2). The first gene therapy drug, Gendicine ${ }^{\mathrm{TM}}$, developed by SiBiono Gene Tech Co., was approved by the China Food and Drug Administration (CFDA) in 2003, making China the first country to approve a gene therapy-based product for clinical applications ${ }^{69}$. Gendicine $^{\mathrm{TM}}$ is an adenoviral vector with a slight modification wherein the E1 gene is substituted with a human p53 cDNA. Gendicine $\mathrm{TM}^{\mathrm{TM}}$ is a replicationdefective virus engineered to treat patients with tumors carrying a mutated p53 gene, a common cause of more than $50 \%$ of human cancers, including head and neck squamous cell carcinoma ${ }^{70,71}$. Two years after approving Gendicine ${ }^{\mathrm{TM}}$, China introduced another gene therapy product known as Oncorine ${ }^{\mathrm{TM}}$, developed by Sunway Biotech Co., Ltd. Oncorine ${ }^{\mathrm{TM}}$ is a conditionally replicative Ad that functions to treat advanced-stage refractory nasopharyngeal cancer. The E1B 55K was removed from the adenoviral vector in the construction of Oncorine ${ }^{\mathrm{TM}}$, thus preventing replication in normal cells. Without E1B 55K activity, replication can occur only in p53-deficient cells, which are malignant. Viral replication in malignant cells causes oncolysis, indicating that this product will greatly contribute to the therapy of solid tumors ${ }^{69}$. On July 19, 2012, the European Union approved the first AAV1-based gene therapy drug, alipogene tiparvovec or Glybera ${ }^{\mathrm{TM}}$, a gene therapy product used for the treatment of severe lipoprotein lipase deficiency (LPLD), a rare monogenic disorder characterized by the accumulation of triglycerides in the plasma due to mutations in LPL; however, this product was later withdrawn from the market. Later, in 2016, the European Union approved another ex vivo HSC gene therapy named Strimvelis ${ }^{\mathrm{TM}}$ to treat ADASCID. Strimvelis ${ }^{\mathrm{TM}}$ consists of a single corrected autologous gene infusion, modified using a $\gamma$-RV vector $^{78}$.

\section{CHALLENGES AND HURDLES IN GENE THERAPY/RISKS OF GENE THERAPY}

Although gene therapy has enormous potential, several adverse events due to risks associated with the viral vector have been reported. The first adverse event happened in 1999 at the University of Pennsylvania, where a gene therapy involving Ad administration resulted in the death of 18-year-old Jesse Gelsinger, who suffered from a partial deficiency of ornithine transcarbamylase (OTC). OTC is a liver enzyme that removes excess nitrogen from amino acids and proteins ${ }^{64,79}$. After 4 days of treatment, Gelsinger died due to a hyperimmune reaction after a very high dose of Ad caused his organs to stop functioning.

The impressive success of gene therapy clinical trials for SCID-X1 in 2000 gave rise to a new era of therapeutics using RVs as vectors. First, a clinical trial was successfully conducted involving five patients who underwent RV-mediated transfer of the $\gamma_{c}$ gene into CD $34^{+}$cells. The second trial involved four additional patients, three of whom were doing well up to 3.6 years later, whereas the fourth patient died. However, between 30 and 34 months after gene therapy, the three remaining patients developed $\mathrm{T}$ cell leukemia. This was due to proviral integration within the LMO-2 locus located on the short arm of chromosome 11. The proviral integration resulted in aberrant expression of LMO-2, which led to the generation of acute lymphoblastic leukemia from $\mathrm{T}$ cells with the $\alpha / \beta$ receptor. This study highlighted the risk of insertional mutagenesis events directly linked to virusmediated gene transfer ${ }^{80}$.

\section{CONCLUSIONS}

The effectiveness of gene therapy relies heavily on the transfer vector. To date, viral vectors are the best available vehicles due to their relatively high delivery efficiency to most tissues and have been the main vectors used in gene therapy clinical trials. Certain viruses are frequently employed as vectors since they can transport the new gene by infecting the cell and have been engineered not to cause harm to patients. The viral vector's capacity to integrate into the host genome, such as in the case of RVs, results in permanent and persistent gene expression. Although some drawbacks of using viral vectors have been reported, such as random insertion into the host genome that could potentially cause oncogene activation, the limited insertion capacity of target genes, low titers, and inability to transduce non-dividing cells, these drawbacks do not prevent them from unlocking their effective transgene expression potential in gene therapy 
applications.

\section{ABBREVIATIONS}

AAV: Adeno-associated virus

Ad: Adenovirus

ADA-SCID: Adenosine deaminase severe combined immunodeficiency

AIDS: Acquired immunodeficiency syndrome

C.F.: Cystic fibrosis

CFTR: Cystic fibrosis transmembrane conductance regulator

CRISPR: Cluster regularly interspaced short palindromic repeats

HDAdVs: Helper-dependent Ad vectors

HPIV: Human parainfluenza virus

HSV: Herpes simplex virus

LTRs: Long terminal repeats

LV: Lentivirus

MIDGE: Minimalistic, immunological-defined gene expression

MLV: Murine leukaemia virus

OTC: Ornithine transcarbamylase

rAAV: Recombinant AAV

SCID: Severe combined immunodeficiency

SeV: Sendai virus

siRNA: Small interfering RNA sequences

\section{ACKNOWLEDGMENTS}

We thank all the authors who have made substantive contributions to this article.

\section{AUTHOR'S CONTRIBUTIONS}

Nur Shuhaidatul Sarmiza and Noorhanis Abu Halim contributed to the conception and design of the article. Nur Shuhaidatul Sarmiza, Noorhanis Abu Halim, Norashikin Zakaria and Lelamekala participated in drafting the article. Ida Shazrina was involved in the critical revision of the article. Badrul Hisham Yahaya was involved in the review, comments and approved the version to be published.

\section{FUNDING}

This work was supported by Fundamental Research Grant Scheme (FRGS), Ministry of Higher Education Malaysia (203/CIPPT/6711509 and 203/CIPPT/6711725) and Research University Grant Scheme Universiti Sains Malaysia (1001/CIPPT/8012203).

\section{AVAILABILITY OF DATA AND MATERIALS}

Not applicable.

\section{ETHICS APPROVAL AND CONSENT} TO PARTICIPATE

Not applicable.

\section{CONSENT FOR PUBLICATION}

Not applicable.

\section{COMPETING INTERESTS}

The authors declare that they have no competing interests.

\section{REFERENCES}

1. Burney TJ, Davies JC. Gene therapy for the treatment of cystic fibrosis. Appl Clin Genet. 2012;5:29-36. PMID: 23776378. Available from: 10.2147/TACG.S8873.

2. Park SH, Bao G. CRISPR/Cas9 gene editing for curing sickle cell disease. Transfusion and Apheresis Science. 2021;60(1):103060. PMID: 33455878. Available from: 10.1016/ j.transci.2021.103060.

3. Rosengart TK, Lee LY, Patel SR, Kligfield PD, Okin PM, Hackett NR, et al. Six-month assessment of a phase I trial of angiogenic gene therapy for the treatment of coronary artery disease using direct intramyocardial administration of an adenovirus vector expressing the VEGF121 cDNA. 1999;230(4):466-70. PMID: 10522716. Available from: 10. 1097/00000658-199910000-00002.

4. Freytag SO, Stricker $\mathrm{H}$, Movsas $\mathrm{B}, \mathrm{Kim} \mathrm{JH}$. Prostate cancer gene therapy clinical trials. Molecular Therapy. 2007;15(6):1042-52. PMID: 17406342. Available from: 10.1038/sj.mt.6300162.

5. DiGiusto DL, Krishnan A, Li L, Li H, Li S, Rao A. RNA-based gene therapy for HIV with lentiviral vector-modified CD34(+) cells in patients undergoing transplantation for AIDS-related lymphoma. Science Translational Medicine. 2010;2(36). PMID: 20555022. Available from: 10.1126/scitranslmed.3000931.

6. Sung YK, Kim SW. Recent advances in the development of gene delivery systems. Biomaterials Research. 2019;23(1):8. PMID: 30915230. Available from: 10.1186/s40824-019-0156-z.

7. Chen J, Reeves L, Cornetta K. Safety testing for replicationcompetent retrovirus associated with gibbon ape leukemia virus-pseudotyped retroviral vectors. Human Gene Therapy. 2001;12(1):61-70. PMID: 11177543. Available from: 10.1089/ 104303401450979.

8. Kirik D, Georgievska B, Björklund A. Localized striatal delivery of GDNF as a treatment for Parkinson disease. Nature Neuroscience. 2004;7(2):105-10. PMID: 14747832. Available from: $10.1038 / \mathrm{nn} 1175$.

9. Klein RL, Dayton RD, Tatom JB, Henderson KM, Henning PP. AAV8, 9, Rh10, Rh43 vector gene transfer in the rat brain: effects of serotype, promoter and purification method. Molecular Therapy. 2008;16(1):89-96. PMID: 17955025. Available from: 10.1038/sj.mt.6300331.

10. Lukashev AN, Zamyatnin AA. Viral vectors for gene therapy: Current state and clinical perspectives. Vol. 81, Biochemistry (Moscow). Maik Nauka Publishing / Springer SBM; 2016. p. 700-8.

11. Lundstrom K. New frontiers in oncolytic viruses: Optimizing and selecting for virus strains with improved efficacy. Biologics. 2018;12:43-60. PMID: 29445265. Available from: 10.2147/BTT.S140114.

12. Lentz TB, Gray SJ, Samulski RJ. Viral vectors for gene delivery to the central nervous system. Neurobiology of Disease. 2012;48(2):179-88. PMID: 22001604. Available from: 10.1016/j.nbd.2011.09.014. 
13. Penaud-Budloo $M$, Guiner $C L$, Nowrouzi $A$, Toromanoff $A$, Chérel $Y$, Chenuaud P. Adeno-associated virus vector genomes persist as episomal chromatin in primate muscle. Journal of Virology. 2008;82(16):7875-85. PMID: 18524821. Available from: 10.1128/JVI.00649-08.

14. Anguela XM, High KA. Entering the modern era of gene therapy. Annual Review of Medicine. 2019;70(1):273-88. PMID 30477394. Available from: 10.1146/annurev-med-012017043332.

15. Wold W, Toth K. Adenovirus Vectors for Gene Therapy, Vaccination and Cancer Gene Therapy. Current Gene Therapy. 2014;13(6):421-33. PMID: 24279313. Available from: 10.2174/ 1566523213666131125095046

16. Yamamoto M, Curiel DT. Current issues and future directions of oncolytic adenoviruses. Molecular Therapy. 2010;18(2):243-50. PMID: 19935777. Available from: 10.1038/ mt.2009.266.

17. Volpers $C$, Kochanek $S$. Adenoviral vectors for gene transfer and therapy. The Journal of Gene Medicine. 2004;6(S1):16471. PMID: 14978759 . Available from: 10.1002/jgm.496.

18. Merten OW, Gaillet B. Viral vectors for gene therapy and gene modification approaches. Biochemical Engineering Journal. 2016;108:98-115. Available from: 10.1016/j.bej.2015.09.005.

19. Müther N, Noske N, Ehrhardt A. Viral hybrid vectors for somatic integration - are they the better solution? Viruses. 2009;1(3):1295-324. PMID: 21994594. Available from: 10. 3390/v1031295.

20. Crystal RG. Adenovirus: the first effective in vivo gene delivery vector. Human Gene Therapy. 2014;25(1):3-11. PMID: 24444179. Available from: 10.1089/hum.2013.2527.

21. Stephen SL, Montini E, Sivanandam VG, Al-Dhalimy M, Kestler $\mathrm{HA}$, Finegold M. Chromosomal integration of adenoviral vector DNA in vivo. Journal of Virology. 2010;84(19):9987-94. PMID: 20686029. Available from: 10.1128/JVI.00751-10.

22. Muruve DA. The innate immune response to adenovirus vectors. Human Gene Therapy. 2004;15(12):1157-66. PMID: 15684693. Available from: 10.1089/hum.2004.15.1157.

23. Zaiss AK, Vilaysane A, Cotter MJ, Clark SA, Meijndert HC, Colarusso P. Antiviral antibodies target adenovirus to phagolysosomes and amplify the innate immune response. Journal of Immunology (Baltimore, Md: 1950). 2009;182(11):7058-68. PMID: 19454703. Available from: 10.4049/jimmunol.0804269.

24. Brunetti-Pierri N, Ng P. Helper-Dependent Adenoviral Vectors. In: Adenoviral Vectors for Gene Therapy: Second Edition. 2016. . Available from: 10.1016/B978-0-12-800276-6.00017-6.

25. Brunetti-Pierri N, Ng P. Helper-dependent adenoviral vectors for liver-directed gene therapy. Human Molecular Genetics. 2011;20:7-13. PMID: 21470977. Available from: 10.1093/hmg/ ddr143.

26. Piccolo P, Brunetti-Pierri N. Challenges and prospects for helper-dependent adenoviral vector-mediated gene therapy. Biomedicines. 2014;2(2):132-48. PMID: 28548064. Available from: 10.3390/biomedicines2020132.

27. Damme AV, Chuah MK, Dell'accio F, Bari CD, Luyten F, Collen $D$. Bone marrow mesenchymal cells for haemophilia A gene therapy using retroviral vectors with modified long-terminal repeats. Haemophilia. 2003;9(1):94-103. PMID: 12558785. Available from: 10.1046/j.1365-2516.2003.00709.x.

28. Rosenberg S, Aebersold P, Cornetta K, Kasid A, Morgan RA, Moen $R$, et al. Gene transfer into humans immunotherapy of patients with advanced melanoma, using tumor-infiltrating lymphocytes modified by retroviral gene transduction. The New England Journal of Medicine. 1990;323(9):570-8. PMID: 2381442. Available from: 10.1056/NEJM199008303230904

29. Das SK, Menezes ME, Bhatia S, Wang XY, Emdad L, Sarkar D. Gene Therapies for Cancer: Strategies, Challenges and Successes. Journal of Cellular Physiology. 2015;230(2):259-71. PMID: 25196387. Available from: 10.1002/jcp.24791.

30. McCormack MP, Rabbitts TH. Activation of the T-cell oncogene LMO2 after gene therapy for X-linked severe combined immunodeficiency. The New England Journal of Medicine.
2004;350(9):913-22. PMID: 14985489. Available from: 10 1056/NEJMra032207.

31. Hacein-Bey-Abina S, Garrigue A, Wang GP, Soulier J, Lim $A$, Morillon E. Insertional oncogenesis in 4 patients after retrovirus-mediated gene therapy of SCID-X1. The Journal of Clinical Investigation. 2008;118(9):3132-42. PMID: 18688285. Available from: 10.1172/JCI35700.

32. Gabriel R, Schmidt $M$, von Kalle $C$. Integration of retroviral vectors. Current Opinion in Immunology. 2012;24(5):592-7. PMID: 22981243. Available from: 10.1016/j.coi.2012.08.006.

33. Naldini L, Blömer U, Gallay P, Ory D, Mulligan R, Gage FH, et al. In vivo gene delivery and stable transduction of nondividing cells by a lentiviral vector. Science. 1996;272(5259):263-7. PMID: 8602510. Available from: 10.1126/science.272.5259.263.

34. Miller DG, Adam MA, Miller AD. Gene transfer by retrovirus vectors occurs only in cells that are actively replicating at the time of infection. Molecular and Cellular Biology. 1990;10(8):4239-42. PMID: 2370865. Available from: 10.1128/MCB.10.8.4239.

35. Naldini L, Blömer U, Gage FH, Trono D, Verma IM. Efficient transfer, integration, and sustained long-term expression of the transgene in adult rat brains injected with a lentiviral vector. Proceedings of the National Academy of Sciences of the United States of America. 1996;93(21):11382-8. PMID: 8876144. Available from: 10.1073/pnas.93.21.11382.

36. Felice B, Cattoglio C, Cittaro D, Testa A, Miccio A, Ferrari G. Transcription factor binding sites are genetic determinants of retroviral integration in the human genome. PLoS One. 2009;4(2):e4571. PMID: 19238208. Available from: 10.1371/ journal.pone.0004571.

37. Aiuti A, Biasco L, Scaramuzza S, Ferrua F, Cicalese MP, Baricordi $C$, et al. Lentiviral hematopoietic stem cell gene therapy in patients with wiskott-aldrich syndrome. Science. 2013;341(6148):1233151. PMID: 23845947. Available from: $10.1126 /$ science. 1233151

38. Wanisch K, Yáñez-Muñoz RJ. Integration-deficient lentiviral vectors: a slow coming of age. Molecular Therapy. 2009;17(8):1316-32. PMID: 19491821. Available from: 10. $1038 / \mathrm{mt} .2009 .122$

39. Berges BK, Wolfe JH, Fraser NW. Transduction of brain by herpes simplex virus vectors. Molecular Therapy. 2007;15(1):209. PMID: 17164771. Available from: 10.1038/sj.mt.6300018.

40. Jackson SA, DeLuca NA. Relationship of herpes simplex virus genome configuration to productive and persistent infections. Proceedings of the National Academy of Sciences of the United States of America. 2003;100(13):7871-6. PMID: 12796511. Available from: $10.1073 /$ pnas.1230643100.

41. Berges BK, Yellayi S, Karolewski BA, Miselis RR, Wolfe JH, Fraser NW. Widespread correction of lysosomal storage in the mucopolysaccharidosis type VII mouse brain with a herpes simplex virus type 1 vector expressing $\beta$-glucuronidase. Molecular Therapy. 2006;13(5):859-69. PMID: 16515890. Available from: 10.1016/j.ymthe.2005.12.017.

42. Artusi S, Miyagawa Y, Goins WF, Cohen JB, Glorioso JC. Herpes Simplex Virus Vectors for Gene Transfer to the Central Nervous System. Diseases (Basel, Switzerland). 2018;6(3):74. PMID: 30110885. Available from: 10.3390/diseases6030074.

43. Eissa IR, Naoe $Y$, Bustos-Villalobos I, Ichinose T, Tanaka M Zhiwen W. Genomic signature of the natural oncolytic herpes simplex virus HF10 and its therapeutic role in preclinical and clinical trials. Frontiers in Oncology. 2017;7:149. PMID: 28770166. Available from: 10.3389/fonc.2017.00149.

44. Cuchet D, Potel C, Thomas J, Epstein AL. HSV-1 amplicon vectors: a promising and versatile tool for gene delivery. Expert Opinion on Biological Therapy. 2007;7(7):975-95. PMID: 17665988. Available from: 10.1517/14712598.7.7.975.

45. Jerusalinsky D, Baez MV, Epstein AL. Herpes simplex virus type 1-based amplicon vectors for fundamental research in neurosciences and gene therapy of neurological diseases. Journal of Physiology, Paris. 2012;106(1-2):2-11. PMID: 22108428. Available from: 10.1016/j.jphysparis.2011.11.003. 
46. Chen RF, Lee CY. Adenoviruses types, cell receptors and local innate cytokines in adenovirus infection. International Reviews of Immunology. 2014;33(1):45-53. PMID: 24127823. Available from: 10.3109/08830185.2013.823420.

47. Wolfrum N, Greber UF. Adenovirus signalling in entry. Cellular Microbiology. 2013;15(1):53-62. PMID: 23083122. Available from: $10.1111 / \mathrm{cmi} .12053$

48. Weitzman MD, Fisher KJ, Wilson JM. Recruitment of wild-type and recombinant adeno-associated virus into adenovirus replication centers. Journal of Virology. 1996;70(3):1845-54. PMID: 8627709. Available from: 10.1128/jvi.70.3.1845-1854. 1996.

49. Nayak S, Herzog RW. Progress and prospects: immune responses to viral vectors. Gene Therapy. 2010;17(3):295-304. PMID: 19907498. Available from: 10.1038/gt.2009.148.

50. Lin J, Calcedo R, Vandenberghe LH, Bell P, Somanathan S, Wilson JM. A new genetic vaccine platform based on an adenoassociated virus isolated from a rhesus macaque. Journal of Virology. 2009;83(24):12738-50. PMID: 19812149. Available from: 10.1128/JVI.01441-09.

51. Deyle DR, Russell DW. Adeno-associated virus vector integration. Current Opinion in Molecular Therapeutics. 2009;11(4):442-7. PMID: 19649989.

52. Nathwani AC, Davidoff AM, Tuddenham EG. Gene Therapy for Hemophilia. Hematology/Oncology Clinics of North America. 2017;31(5):853-68. PMID: 28895852. Available from: 10.1016/ j.hoc.2017.06.011.

53. Batty P, Lillicrap D. Advances and challenges for hemophilia gene therapy. Human Molecular Genetics. 2019;28:95-101. PMID: 31332444 . Available from: 10.1093/hmg/ddz157.

54. Mingozzi F, High KA. Immune responses to AAV vectors: overcoming barriers to successful gene therapy. Blood. 2013;122(1):23-36. PMID: 23596044. Available from: 10.1182/ blood-2013-01-306647.

55. Hocquemiller M, Giersch L, Audrain M, Parker S, Cartier N. Adeno-Associated Virus-Based Gene Therapy for CNS Diseases. Human Gene Therapy. 2016;27(7):478-96. PMID: 27267688. Available from: 10.1089/hum.2016.087.

56. Donsante A, Miller DG, Li Y, Vogler C, Brunt EM, Russell DW et al. AAV vector integration sites in mouse hepatocellular carcinoma. Science. 2007;317(5837):477. PMID: 17656716. Available from: $10.1126 /$ science. 1142658 .

57. Francis JS, Markov V, Wojtas ID, Gray S, McCown T, Samulski RJ. Preclinical biodistribution, tropism, and efficacy of oligotropic AAV/Olig001 in a mouse model of congenital white matter disease. Molecular Therapy Methods \{\&amp;\}amp; Clinical Development. 2021;20:520-34. PMID: 33614826. Available from: 10.1016/j.omtm.2021.01.009.

58. Freytag SO, Khil M, Stricker H, Peabody J, Menon M, DePeraltaVenturina $M$. Phase I study of replication-competent adenovirus-mediated double suicide gene therapy for the treatment of locally recurrent prostate cancer. Cancer Research. 2002;62(17):4968-76. PMID: 12208748.

59. Zhou H, He Z, Wang C, Xie T, Liu L, Liu C. Intravenous administration is an effective and safe route for cancer gene therapy using the bifidobacterium-mediated recombinant HSV-1 Thymidine Kinase and Ganciclovir. International Journal of Molecular Sciences. 2016;17(6):891. PMID: 27275821. Available from: 10.3390/ijms17060891.

60. Watanabe M, Boyer JL, Crystal RG. AAVrh.10-mediated genetic delivery of bevacizumab to the pleura to provide local antiVEGF to suppress growth of metastatic lung tumors. Gene Therapy. 2010;17(8):1042-51. PMID: 20596059. Available from: $10.1038 /$ gt.2010.87.

61. Lavu M, Gundewar S, Lefer DJ. Gene therapy for ischemic heart disease. Journal of Molecular and Cellular Cardiology. 2011;50(5):742-50. PMID: 20600100. Available from: 10.1016/ j.yjmcc.2010.06.007.

62. Heguy A, Crystal RG. Intrapleural 'outside-in' gene therapy: therapeutics for organs of the chest via gene transfer to the pleura. Current Opinion in Molecular Therapeutics. 2005;7(5):440-53. PMID: 16248279.
63. Ginn SL, Amaya AK, Alexander IE, Edelstein M, Abedi MR. Gene therapy clinical trials worldwide to 2017: an update. The Journal of Gene Medicine. 2018;20(5):e3015. PMID: 29575374 Available from: 10.1002/jgm.3015.

64. Shahryari A, Jazi MS, Mohammadi S, Nikoo HR, Nazari Z, Hosseini ES, et al. Development and clinical translation of approved gene therapy products for genetic disorders. Front Genet. 2019;10:868. PMID: 31608113. Available from: 10.3389/ fgene.2019.00868.

65. Rosenberg SA, Aebersold P, Cornetta K, Kasid A, Morgan RA, Moen R, et al. Gene transfer into humans immunotherapy of patients with advanced melanoma, using tumor-infiltrating lymphocytes modified by retroviral gene transduction. The New England Journal of Medicine. 1990;323(9):570-8. PMID: 2381442. Available from: 10.1056/NEJM199008303230904.

66. Cotrim AP, Baum BJ. Gene therapy: some history, applications, problems, and prospects. Toxicologic Pathology. 2008;36(1):97-103. PMID: 18337227. Available from: 10.1177/ 0192623307309925.

67. Markert JM, Liechty PG, Wang W, Gaston S, Braz E, Karrasch M. Phase lb trial of mutant herpes simplex virus $\mathrm{G} 207$ inoculated pre-and post-tumor resection for recurrent GBM. Molecular Therapy. 2009;17(1):199-207. PMID: 18957964. Available from: $10.1038 / \mathrm{mt} .2008 .228$.

68. Markert JM, Razdan SN, Kuo HC, Cantor A, Knoll A, Karrasch M A phase 1 trial of oncolytic HSV-1, G207, given in combination with radiation for recurrent GBM demonstrates safety and radiographic responses. Molecular Therapy. 2014;22(5):104855. PMID: 24572293. Available from: 10.1038/mt.2014.22.

69. Zabner J, Zeiher BG, Friedman E, Welsh MJ. Adenovirusmediated gene transfer to ciliated airway epithelia requires prolonged incubation time. Journal of Virology. 1996;70(10):6994-7003. PMID: 8794344. Available from: 10.1128/jvi.70.10.6994-7003.1996.

70. Zhang Z, Stiegler AL, Boggon TJ, Kobayashi S, Halmos B. EGFRmutated lung cancer: a paradigm of molecular oncology. Oncotarget. 2010;1(7):497-514. PMID: 21165163. Available from: 10.18632/oncotarget.186.

71. Ferrari S, Griesenbach U, lida A, Farley R, Wright AM, Zhu J. Sendai virus-mediated CFTR gene transfer to the airway epithelium. Gene Therapy. 2007;14(19):1371-9. PMID: 17597790. Available from: 10.1038/sj.gt.3302991.

72. Griesenbach $U$, Inoue M, Hasegawa M, Alton EW. Inoue, Hasegawa, Alton. Viral vectors for cystic fibrosis gene therapy: what does the future hold? Virus Adaptation and Treatment. 2010;2:159-171. Available from: 10.2147/VAAT.S8887.

73. Yan Z, McCray PB, Engelhardt JF. Advances in gene therapy for cystic fibrosis lung disease. Human Molecular Genetics. 2019;28:88-94. PMID: 31332440. Available from: 10.1093/ $\mathrm{hmg} / \mathrm{ddz} 139$.

74. Thompson AA, Walters MC, Kwiatkowski J, Rasko JE, Ribeil JA, Hongeng S. Gene Therapy in Patients with TransfusionDependent $\beta$-Thalassemia. The New England Journal of Medicine. 2018;378(16):1479-93. PMID: 29669226. Available from: 10.1056/NEJMoa1705342.

75. Bulcha JT, Wang Y, Ma H, Tai PW, Gao G. Viral vector platforms within the gene therapy landscape. Signal Transduction and Targeted Therapy. 2021;6(1):53. PMID: 33558455. Available from: 10.1038/s41392-021-00487-6.

76. Verges $C$, Odland J, Auderset ME, Komlos D. American Society of Gene and Cell Therapy (ASGCT) - 23rd Annual Meeting. Virtual Format - May 12-15, 2020. Drugs Fut. 2020;45(7):527. Available from: 10.1358/dof.2020.45.7.3176878.

77. Dalkara D, Byrne LC, Klimczak RR, Visel M, Yin L, Merigan WH, et al. In vivo-directed evolution of a new adeno-associated virus for therapeutic outer retinal gene delivery from the vitreous. Science Translational Medicine. 2013;5(189):189ra76. PMID: 23761039. Available from: 10.1126/scitranslmed. 3005708.

78. Aiuti A, Roncarolo MG, Naldini L. Gene therapy for ADASCID, the first marketing approval of an ex vivo gene ther- 
apy in Europe: paving the road for the next generation of advanced therapy medicinal products. EMBO Molecular Medicine. 2017;9(6):737-40. PMID: 28396566. Available from: 10.15252/emmm.201707573.

79. Yin H, Kanasty RL, Eltoukhy AA, Vegas AJ, Dorkin JR, Anderson DG. Non-viral vectors for gene-based therapy. Nature Reviews
Genetics. 2014;15(8):541-55. PMID: 25022906. Available from: $10.1038 / \mathrm{nrg} 3763$.

80. Schakowski F, Gorschlüter M, Buttgereit P, Märten A, LilienfeldToal M, Junghans $C$, et al. Minimal size MIDGE vectors improve transgene expression in vivo. In Vivo. 2007;21(1):17-23. PMID: 17354609. 
Ready to submit your manuscript? Choose Biomedpress and benefit from:

- Fast, convenient online submission

- Through peer-review by experienced researchers

- Rapid publication on acceptance

- Free of charge (without publication fees)

Learn more http://www.biomedpress.org/journals/
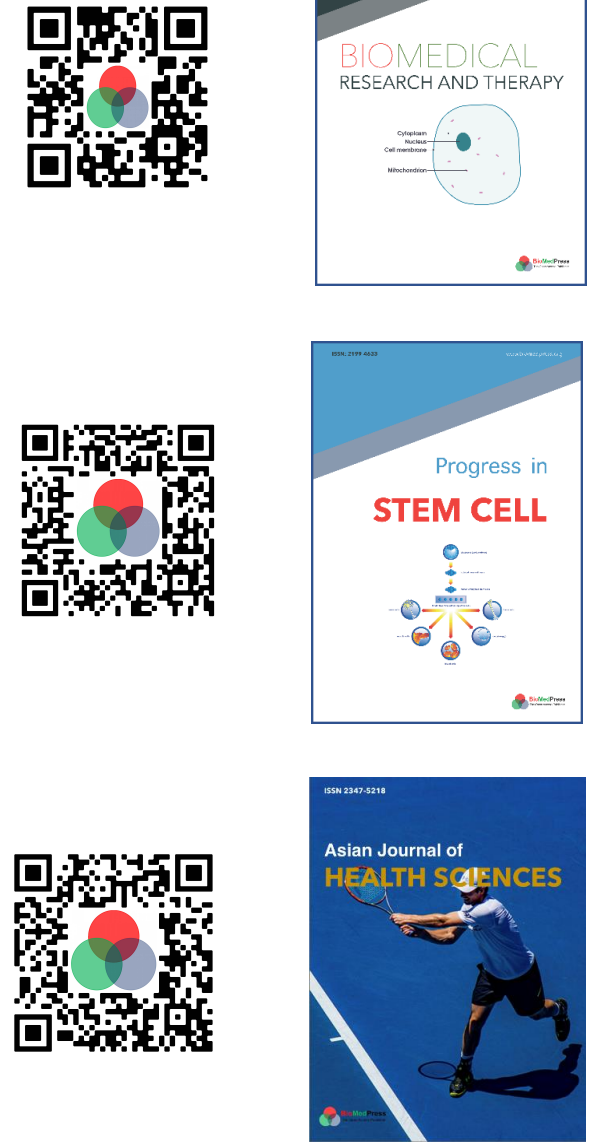

Asian Journal of Health Sciences

ISSN: 2347-5218

Indexed: Google Scholar

Acceptance Rate (2020): 72.89\%

Article Publishing Charge: Free

Submission to first editorial decision: 16.5 days

Biotechnological Research

ISSN: 2395-6763

Indexed: Google Scholar

Acceptance Rate (2020): $67.02 \%$

Article Publishing Charge: Free

Submission to first editorial decision: 28.5 days 